\title{
Empiriese bevindings aangaande die nakoming van korporatiewe beheerriglyne in jaarverslae van sekere genoteerde Suid-Afrikaanse maatskappye
}

\author{
Q Vorster \\ Departement Rekeningkunde \\ en Finansiële Bestuur \\ Universiteit van Pretoria
}

\author{
D S Lubbe \\ OTK-Navorsingseenheid \\ vir Sake-etiek \\ UOVS
}

\begin{abstract}
The implementation of the principles of corporate governance by South African companies has increased considerably since the release of the King Report in 1994. This report exerted a great influence, especially regarding the disclosure of information on corporate governance in the annual financial statements of companies. Several research projects have been undertaken to determine to what extent companies abide by these principles in their annual financial statements. This article reflects the results of a research project in which the annual financial statements of certain listed South African companies, which were published during 2000, were analysed with regard to the above-mentioned matter. The results of the project are also compared with those of a similar project undertaken in 1999. The matters addressed in this article deal with inter alia directors and directors' remuneration, remuneration committees, audit committees, codes of conduct, adherence to the King Report and employees' involvement.
\end{abstract}

Key words

Corporate governance

Audit committees

Directors of companies

\section{Trefwoorde}

Korporatiewe beheer

Ouditkomitees

Maatskappydirekteure

Contact the editor if you require the article in English. 


\section{$1 \quad$ Inleiding}

Die jaar 2000 sal waarskynlik in die geskiedenis van Suid-Afrika opgeteken staan as die jaar waarin korporatiewe beheeraangeleenthede oor 'n wye spektrum in die land aan die orde gestel is. Eerstens het die Public Finance Management Act (Wet no. 1 van 1999) op 1 April 2000 van krag geword en die gepaardgaande regulasies op 1 Junie 2000. Hierdie wetgewing en regulasies is hoofsaaklik gemik op nasionale en provinsiale staatsdepartemente en ander "semi-staatsinstellings". Die grondslag van hierdie wet en regulasies kan grootliks teruggevoer word na die beginsels van goeie korporatiewe beheer wat, sedert die uitreiking van amptelike verslae oor korporatiewe beheer (soos die King-verslag, The Institute of Directors in Southern Africa 1994) in Suid-Afrika, 'n wesenlike invloed op finansiële verslagdoening, samestelling van direksies, rol en funksies van verskeie rolspelers en vele ander aspekte in die privaatsektor uitgeoefen het. Hierdie wetgewing, asook die konsepwetgewing waarna hieronder verwys word, hou wesenlike risiko's en implikasies vir staatsamptenare en politici in (vergelyk byvoorbeeld Lubbe \& Henning 2000 (a), Lubbe \& Henning 2000 (b), Lubbe \& Henning 2000 (c)). Dit is duidelik dat korporatiewe beheer in 'n baie kort tyd alle vlakke van die samelewing drasties begin raak het en nie meer slegs die groot internasionale maatskappye in ontwikkelde Westerse lande beïnvloed nie.

Gedurende Augustus 2000 het daar ook prominente berigte in die media verskyn (vergelyk bv. Marrs 2000, Von Keyserlingk 2000) wat daarop dui dat die King-verslag indringend hersien gaan word. Die King-verslag (1994:35) meld dat korporatiewe beheer inderwaarheid 'n "moving target" vir ondernemings in die een en twintigste eeu is. Indien in ag geneem word dat hierdie verslag slegs ongeveer ses jaar gelede uitgereik is, dat talle groot genoteerde maatskappye nog nie eens kan verklaar dat hulle ten volle aan al die beginsels daarvan voldoen nie en dat die verslag reeds weer indringend hersien moet word, is dit nie vergesog om korporatiewe beheer inderdaad te sien as 'n bewegende teiken vir die toekoms nie. Verskeie aangeleenthede kan die voorafgaande staaf en andui hoe vinnig korporatiewe beheeraangeleenthede inderwaarheid ontwikkel. 'n Voorbeeld hiervan is die verantwoordelikhede van ouditkomitees wat ingevolge goeie korporatiewe beheerbeginsels deur instansies ingestel moet word. Die King-verslag (vergelyk byvoorbeeld 1994:31) ken primêr twee verantwoordelikhede aan sodanige komitees toe, naamlik aangeleenthede aangaande doeltreffende interne beheer en angaande finansiële verslagdoening. Baie min klem word direk op die ouditkomitee se rol met betrekking tot risikobestuursaangeleenthede geplaas. Hierteenoor lê meer onlangse verslae en ander publikasies soos, die sogenaamde Blue Ribbon-verslag (Securities and Exchange Commission (SEC), The New York Stock Exchange (NYSE) \& The National Association of Securities Dealers (NASD) 1999, PricewaterhouseCoopers 1999; KPMG 1999) al hoe meer

$200 \quad$ Meditari Accountancy Research Vol. 8 2000: 199-214


klem op risikobestuursaangeleenthede en die rol van die ouditkomitee in dié verband.

Teen die bogenoemde agtergrond is daar gedurende 1999 'n navorsingsprojek onderneem ten einde te bepaal in welke mate genoteerde maatskappye in Suid-Afrika aan sekere van die beginsels van korporatiewe beheer, soos in die King-verslag vervat, voldoen. Die resultaat van hierdie projek is weergegee in ' $\mathrm{n}$ artikel in Meditari (Vorster \& Lubbe 1999). In die lig van die snelveranderende vereistes van korporatiewe beheer en ontwikkelinge in dié verband, is daar in die genoemde artikel gemeld dat hierdie projek op 'n jaarlikse basis herhaal sal word ten einde vordering ten opsigte van die implementering van korporatiewe beheeraangeleenthede te moniteer. Hierdie artikel gee die resultate weer van die navorsingsprojek wat gedurende 2000 onderneem is. Die doel met hierdie artikel is om uit die jaarverslae van sekere genoteerde maatskappye in Suid-Afrika aan te dui in welke mate sekere van die voorstelle van die King-verslag reeds deur genoteerde maatskappye geïmplementeer en toegepas word asook om sekere inligting uit die ontleding van die genoemde state weer te gee wat moontlik as riglyne in dié verband kan dien.

\section{Navorsingsmetodologie}

Ten einde te bepaal in welke mate sekere genoteerde maatskappye in SuidAfrika aan bepaalde voorstelle van die King-verslag voldoen, kon daar van verskillende metodes, soos byvoorbeeld die uitstuur van vraelyste of die voer van onderhoude met belanghebbendes gebruik gemaak word. Een van die beginsels van korporatiewe beheer is doeltreffende kommunikasie aan al die uiteenlopende groepe belanghebbendes (vergelyk byvoorbeeld die Kingverslag 1994:16-18). Die belangrikste kommunikasiemiddel in dié verband is waarskynlik die jaarverslag van die maatskappy. In die lig hiervan is besluit om 'n kontrolelys te ontwikkel ten opsigte van die belangrikste riglyne van die King-verslag en om die jaarverslae van 167 genoteerde Suid Afrikaanse maatskappye aan die hand daarvan te ontleed.

In die 1999-projek, waarna in 1 verwys is, is die finansiële jaarstate van alle maatskappye, met 'n boekjaareinde gedurende die kalenderjaar 1998, wat op die Johannesburgse Effektebeurs genoteer is, as teikengroep geneem. Al die maatskappye se jaarverslae wat gedurende 1999 uitgereik is, is aan die hand van die genoemde kontrolelys ontleed. Hierdie benadering het egter talle praktiese probleme opgelewer waarvan die belangrikste was dat dit soms baie moeilik was om veral finansiële jaarstate van "kleiner" genoteerde maatskappye vir die doeleindes van die ontleding te bekom. Verder was daar ook gevalle waar, veral, sodanige "kleiner" maatskappye se state op 'n laat stadium uitgereik is en die afhandeling van die projek vertraag het. In die lig daarvan is besluit om slegs die 167 maatskappye by 
die 2000-projek in te sluit. Die 167 maatskappye bestaan uit die Financial Mail se top 100 industriële maatskappye en die 67 top genoteerde mynboumaatskappye vir 1999, almal gebaseer op die totale waarde van bates. Voorafgaande verandering in die teikengroep moet in gedagte gehou word by die lees van die artikel en veral wanneer die inligting betreffende die twee betrokke jare, soos deur die projekte gedek, vergelyk word. In die algemeen sou 'n mens kon verwag dat die resultate van die huidige projek "beter vordering" ten opsigte van die imlementering van korporatiewe beheeraangeleenthede sou toon, veral in die lig daarvan dat slegs die 167 "top" Suid-Afrikaanse maatskappye se resultaat hierin vervat is, dat hierdie maatskappye deur die finansiële media meer in die "publieke oog" geplaas word en dat "portuurdruk" tussen hierdie "uitgelese" groep maatskappye uitgeoefen word om sover moontlik aan die beginsels van die King-verslag te voldoen.

Die aspekte wat in die kontrolelys gedek word, kan onder die volgende sewe hoofde saamgevat word:

- $\quad$ Plasing van sekere inligting in die jaarverslag

- Direkteure

- Vergoedingskomitees

- Ouditkomitees

- Interne oudit

- $\quad$ Etiese kodes en die onderskrywing van die King-verslag

- Risiko

- Werknemerbetrokkenheid

Die res van die artikel word hiervolgens ingedeel. Vergelykende syfers en persentasies uit die 1999-projek word sover moontlik in afsonderlike kolomme in tabelle of tussen hakies na die huidige projek se resultate weergegee.

\section{$3 \quad$ Plasing van bepaalde inligting in die jaarverslag}

'n Aangeleentheid wat vanjaar vir die eerste keer ondersoek is, is die plasing van korporatiewe beheeraangeleenthede in die jaarverslag. In $86 \%$ van die gevalle wat ondersoek is, word 'n afsonderlike verslag oor aangeleenthede van korporatiewe beheer as deel van die jaarverslag verstrek, terwyl dit in $7 \%$ van die gevalle wat ondersoek is in die direkteursverslag behandel is. In 'n verdere $7 \%$ van die gevalle word ander verslae vir dié doel aangewend of word dit verstrek in verskeie van die aangebode verslae wat deel van die jaarverslag vorm.

\section{Direkteure}

\subsection{Inleiding}


Die King-verslag (1994:8-10) lê groot klem daarop dat die direksie 'n belangrike rol in die proses van korporatiewe beheer speel. Die rol van veral onafhanklike, nie-uitvoerende direkteure in dié verband is ' $\mathrm{n}$ aangeleentheid wat in die verslag beklemtoon word (1994:10-13) en 'n groot deel van die verslag handel oor die rol en funksie van die direksie en in die besonder dié van nie-uitvoerende direkteure.

\subsection{Samestelling en agtergrond van direksies}

Daar bestaan geen algemeen aanvaarbare riglyne oor die grootte en samestelling van 'n direksie nie. Hierdie ondersoek het die volgende aan die lig gebring:

\section{Tabel 1}

\begin{tabular}{|c|c|c|}
\hline \multicolumn{3}{|c|}{$\begin{array}{c}\text { Kategorisering van maatskappye in terme van getal } \\
\text { direkteure }\end{array}$} \\
\hline & 2000-projek & 1999-projek \\
\hline Minder as vyf direkteure & $4,2 \%$ & $9,5 \%$ \\
\hline 5-9 direkteure & $42,4 \%$ & $50,5 \%$ \\
\hline 10-14 direkteure & $38,8 \%$ & $30,0 \%$ \\
\hline 15-19 direkteure & $12,7 \%$ & $8,0 \%$ \\
\hline 20 en meer direkteure & $1,9 \%$ & $2,0 \%$ \\
\hline Totaal & $100 \%$ & $100 \%$ \\
\hline
\end{tabular}

Die meerderheid van die maatskappye het tussen 5 en 9 direkteure, soos ook in die vorige ondersoek bevind.

Die King-verslag (1994:12) bepaal dat 'n effektiewe direksie ten minste oor die dienste van twee nie-uitvoerende direkteure moet beskik. Van die jaarverslae wat ondersoek is, het $91 \%$ (22\%) inligting aangaande die onderskeid tussen uitvoerende en nie-uitvoerende direkteure verskaf. Die volgende tabel gee 'n aanduiding van die verdeling tussen uitvoerende en nie-uitvoerende direkteure ten opsigte van maatskappye wat wel die onderskeid getref het:

Tabel 2

\begin{tabular}{|l|l|l|l|l|}
\hline \multicolumn{4}{|c|}{$\begin{array}{c}\text { Kategorisering van maatskappye in terme van } \\
\text { uitvoerende en nie-uitvoerende direkteure }\end{array}$} \\
\hline & \multicolumn{2}{|c|}{ 2000-projek } & \multicolumn{2}{c|}{ 1999-projek } \\
\hline & $\begin{array}{l}\text { Uitvoeren } \\
\text { d }\end{array}$ & $\begin{array}{l}\text { Nie- } \\
\text { uitvoerend }\end{array}$ & $\begin{array}{l}\text { Uitvoeren } \\
\text { d }\end{array}$ & $\begin{array}{l}\text { Nie- } \\
\text { uitvoerend }\end{array}$ \\
\hline
\end{tabular}

Meditari Accountancy Research Vol. 8 2000: 199-214 


\begin{tabular}{|l|c|c|c|c|}
$\begin{array}{l}\text { Minder as vyf } \\
\text { direkteure }\end{array}$ & $60,6 \%$ & $35,8 \%$ & $69,0 \%$ & $61,3 \%$ \\
\hline $5-9$ direkteure & $32,1 \%$ & $53,9 \%$ & $28,0 \%$ & $30,5 \%$ \\
\hline $10-14$ direkteure & $6,7 \%$ & $10,3 \%$ & $3,0 \%$ & $6,7 \%$ \\
\hline $15-19$ direkteure & $0,6 \%$ & & & $0,75 \%$ \\
\hline $\begin{array}{l}20 \text { en meer } \\
\text { direkteure }\end{array}$ & & & & $0,75 \%$ \\
\hline Totaal & $\mathbf{1 0 0} \%$ & $\mathbf{1 0 0} \%$ & $\mathbf{1 0 0} \%$ & $\mathbf{1 0 0} \%$ \\
\hline
\end{tabular}

Hierdie maatskappye het gemiddeld 10 (9) (benader tot die naaste heelgetal) direkteure waarvan gemiddeld 4 (4) uitvoerende direkteure en 6(5) nieuitvoerende direkteure is.

Volgens die betrokke jaarverslae is die kwalifikasies van die direkteure soos volg:

\section{Tabel 3}

\section{Kwalifikasies van direkteure as 'n persentasie van die totaal}

\begin{tabular}{|l|c|c|}
\hline \multirow{2}{*}{\multicolumn{1}{c|}{ Kwalifikasie }} & \multicolumn{2}{|c|}{ Persentasie van totale aantal direkteure } \\
\cline { 2 - 3 } & 2000-projek & 1999-projek \\
\hline GR(SA) & $18,8 \%$ & $22,1 \%$ \\
\hline $\begin{array}{l}\text { Ander kommersiële } \\
\text { kwalifikasies }\end{array}$ & $17,8 \%$ & $22,8 \%$ \\
\hline Ander kwalifikasies & $16,8 \%$ & $18,3 \%$ \\
\hline Nie aangedui nie & $46,6 \%$ & $36,8 \%$ \\
\hline Totaal & $\mathbf{1 0 0} \%$ & $\mathbf{1 0 0} \%$ \\
\hline
\end{tabular}

By slegs $47 \%$ (35\%) van die maatskappye bevat die jaarverslag 'n aanduiding van die aanstellingsvoorwaardes en aftreeprosedures van direkteure (vergelyk byvoorbeeld die King-verslag, 1994:12).

Aangeleentheid wat vanjaar vir die eerste keer ondersoek is, is die vraag of die proses waarvolgens die direksie se prestasie beoordeel word, in die finansiële state openbaar word. In $9 \%$ van die gevalle is sodanige inligting inderdaad openbaar.

\subsection{Die voorsitter van die direksie}

204 Meditari Accountancy Research Vol. 8 2000: 199-214


Ingevolge die beginsels van korporatiewe beheer is dit wenslik dat die ampte van voorsitter van die direksie en dié van uitvoerende hoofbestuurder (besturende direkteur, ens.) nie deur dieselfde persoon beklee sal word nie (vergelyk die King-verslag 1994:13). In die geval van 51\% (47\%) van die jaarverslae is gevind dat die ampte wel geskei is. In die geval van 9\% (13\%) van die jaarverslae was dit nie moontlik om te bepaal of die twee ampte geskei is nie, terwyl by $8 \%(5 \%)$ die ampte deur dieselfde persoon beklee word. In $32 \%$ (35\%) van die gevalle was die voorsitter van die raad 'n uitvoerende direkteur.

\subsection{Inligting wat die direksie moet verskaf}

Een van die verslae wat die King-verslag (1994:19) vereis, is dié deur die direkteure oor die interne beheerstelsel van die onderneming. Die SuidAfrikaanse Instituut van Geoktrooieerde Rekenmeesters (SAIGR 1997) het 'n riglyn uitgereik waarin leiding aan direksies in die verband gegee word. Daar is bevind dat $96 \%$ (93\%) van die maatskappye wel sodanige verslae uitreik. Die meeste van dié verslae, naamlik 81\% (67\%) word in die verslag oor korporatiewe beheer ingesluit. In 7\% (11\%) van die gevalle word die inligting in die direkteursverslag openbaar. In $8 \%(15 \%)$ van die gevalle word die verslag elders in die jaarverslag openbaar.

'n Aangeleentheid wat ook vanjaar vir die eerste keer ondersoek is, is die vraag of daar ' $n$ mening oor die effektiwiteit van interne beheer in die finansiële state verstrek word. In $46 \%$ van die gevalle is aangedui dat dit effektief is, in $18 \%$ dat dit "voldoende" is, in $21 \%$ is ander menings en kommentaar oor die stelsel van interne beheer gelewer en in $15 \%$ van die gevalle is geen duidelike stelling daaroor gemaak nie. Voorts is ook vanjaar vir die eerste keer ondersoek ingestel na die vraag of die verantwoordelikheid van die direksie vir die instandhouding van 'n toepaslike stelsel van interne beheer in die finansiële state erken word. In $80 \%$ van die gevalle aanvaar die direkteure uitdruklik verantwoordelikheid hiervoor, terwyl dit in 10\% van die gevalle aan ander verantwoordelike liggame gedelegeer word. In $10 \%$ van die gevalle word geen duidelike stelling in die verband gemaak nie. In $35 \%$ van die gevalle wat ondersoek is, word spesifiek aangedui dat die direkteure die stelsel van interne beheer moniteer, terwyl die res $(65 \%)$ óf geen duidelike aanduiding in dié verband gee nie óf aandui dat verantwoordelikheid vir die monitering van die stelsel gedelegeer word.

'n Verdere verklaring wat deur die King-verslag (1994:21) vereis word, is die verklaring van die direkteure in die direkteursverslag oor die vermoë van die maatskappy om as lopende saak voort te bestaan. Die SAIGR (1997) het 
eweneens hieroor 'n riglyn opgestel. Daar is bevind dat 93\% (86\%) van die maatskappye wel sodanige verklaring opgestel het. In $43 \%(42 \%)$ van die gevalle verskyn dit in die verslag oor korporatiewe beheer. In $21 \%(18 \%)$ van die gevalle word dit in die direkteursverslag getoon.

\subsection{Verdere verantwoordelikhede van die direksie}

Die King-verslag (1994:27, 28) lê klem daarop dat die direksie in volle en effektiewe beheer van die maatskappy moet wees, dat wesenlike besluite by die direksie moet berus en dat nie-uitvoerende direkteure 'n belangrike moniteringsfunksie moet vervul ten opsigte van die werksaamhede van die uitvoerende direkteure/bestuur.

Die volgende tabel gee ' $n$ aanduiding van die mate waarin hieraan voldoen word:

\section{Tabel 4}

\begin{tabular}{|l|c|c|c|c|}
\hline \multicolumn{2}{|c|}{ Openbaarmaking van verantwoordelikhede van die Raad } \\
\hline \multirow{2}{*}{ Vraag } & 2000-projek & \multicolumn{2}{|c|}{ 1999-projek } \\
\cline { 2 - 5 } & Ja & Nee & Ja & Nee \\
\hline $\begin{array}{l}\text { Is daar 'n aanduiding of die Raad 'n } \\
\text { moniteringsrol t.o.v. uitvoerende } \\
\text { bestuur vervul of nie vervul nie? }\end{array}$ & $61,7 \%$ & $38,3 \%$ & $58,3 \%$ & $41,7 \%$ \\
\hline $\begin{array}{l}\text { Is daar enige aanduiding of die Raad } \\
\text { verklaar dat besluite oor wesenlike } \\
\text { aangeleenthede by die Raad berus? }\end{array}$ & $54,5 \%$ & $45,5 \%$ & $43,4 \%$ & $56,6 \%$ \\
\hline $\begin{array}{l}\text { Is daar enige aanduiding of die Raad } \\
\text { volle en effektiewe beheer oor die } \\
\text { maatskappy uitoefen of nie uitoefen } \\
\text { nie? }\end{array}$ & $42,5 \%$ & $57,5 \%$ & $39,3 \%$ & $60,7 \%$ \\
\hline
\end{tabular}

4.6 Direkteursvergoeding en die vergoedingskomitee

\subsubsection{Inleiding}

Die openbaarmaking van inligting aangaande direkteursvergoeding is tans 'n baie aktuele onderwerp in baie lande en word ook onderstreep deur die wysiging van artikel 297 van die Maatskappywet (Maatskappywysigingswet no. 17 van 1999). Die King-verslag $(1994: 13,14)$ maak verskeie voorstelle in die verband, o.a. dat 'n vergoedingskomitee deur die direksie ingestel moet word.

\subsubsection{Agtergrond en samestelling van die vergoedingskomitee}


In $80 \%(66 \%)$ van die jaarverslae word aangedui dat vergoedings-komitees ingestel is.

Die King-verslag (1994:14) beveel aan dat die voorsitter en die meerderheid van die lede van 'n vergoedingskomitee nie-uitvoerende direkteure sal wees. Die jaarverslae van maatskappye wat voldoende inligting verstrek het, dui aan dat die vergoedingskomitee gemiddeld uit 2 (3) persone bestaan. Altesaam 93\% (77\%) van die maatskappye het aangedui of die vergoedingskomitee uit nie-uitvoerende of uitvoerende direkteure saamgestel is. Uit die inligting oor hierdie groep blyk dit dat $26 \%$ $(30 \%)$ van die vergoedingskomiteelede uitvoerende direkteure en $69 \%$ (67\%) nie-uitvoerende direkteure is, terwyl 2\% (3\%) van die lede van die vergoedingskomitees eksterne persone is wat nie in die direksie dien nie.

Waar die jaarverslae die kwalifikasies van die lede van die vergoedingskomitee aandui, is $21 \%(40 \%)$ van die lede geoktrooieerde rekenmeesters, 19\% (30\%) beskik oor ander kommersiële kwalifikasies en $17 \%(30 \%)$ beskik oor andersoortige kwalifikasies.

Die King-verslag (1994:14) beveel aan dat direkteursvergoeding vir uitvoerende direkteure en nie-uitvoerende direkteure afsonderlik in die jaarverslae getoon sal word. In 63\% (50\%) van die gevalle word 'n onderskeid tussen die vergoeding van uitvoerende en nie-uitvoerende direkteure getref.

'n Nuwe aangeleentheid wat vanjaar vir die eerste keer ondersoek is, is die vraag of die wyse waarop die direkteursvergoeding bepaal word in die finansiële state openbaar word. In $46 \%$ van die gevalle is sodanige inligting inderdaad openbaar. 


\subsubsection{Verslae van die vergoedingskomitee}

Die King-verslag beveel nie aan dat die jaarverslae 'n verslag van die vergoedingskomitee moet bevat nie. Derhalwe bevat slegs 3\% (2\%) van die jaarverslae 'n verslag van die vergoedingskomitee.

\section{$5 \quad$ Ouditkomitees}

\section{$5.1 \quad$ Inleiding}

Verskeie omvattende studies (vergelyk byvoorbeeld Marx 1992; Marx \& Lubbe 1993; Van der Merwe 1996) is reeds in Suid-Afrika onderneem ten einde te bepaal hoeveel maatskappye reeds ouditkomitees ingestel het, hoe sodanige komitees saamgestel is, hoe hulle funksioneer of behoort te funksioneer, ens.

\subsection{Samestelling van die ouditkomitee}

Van die maatskappye wat deel van hierdie ondersoek gevorm het, het $89 \%$ $(80 \%)$ reeds ouditkomitees ingestel. Die huidige ondersoek het aan die lig gebring dat ouditkomitees gemiddeld uit 3 (3) lede bestaan. In 92\% (66\%) van die jaarverslae is aangedui hoe die ouditkomitee saamgestel is. By laasgenoemde groep is $25 \%(27 \%)$ van die ouditkomiteelede uitvoerende direkteure, $70 \%(67 \%)$ is nie-uitvoerende direkteure en $2 \%(6 \%)$ is eksterne persone wat nie in die direksie dien nie.

In die jaarverslae waarin die kwalifikasies van die lede van die ouditkomitee aangedui word, is $51 \%(45 \%)$ van die lede geoktrooieerde rekenmeesters, 31\% (34\%) beskik oor ander kommersiële kwalifikasies, terwyl 18\% (21\%) oor andersoortige kwalifikasies beskik.

\subsection{Verslae van die ouditkomitee}

Die King-verslag beveel nie, soos sekere ander verslae oor korporatiewe beheer, aan dat die jaarverslae 'n verslag van die ouditkomitee moet bevat nie (vergelyk byvoorbeeld Lubbe \& Van der Merwe 1996:16-18). Nieteenstaande dié feit bevat $2 \%(1 \%)$ van die jaarverslae wel 'n verslag van die ouditkomitee. In $84 \%$ (70\%) van die jaarverslae word die belangrikste werksaamhede van die ouditkomitee asook die belangrikste aktiwiteite van die komitee uitgespel. 


\section{$6 \quad$ Interne oudit}

\subsection{Inleiding}

Die King-verslag $(1994: 21,22)$ beskou 'n doeltreffend funksionerende interne ouditafdeling, wat die steun van die hoofbestuur het en wat respek in die onderneming afdwing, as 'n baie belangrike skakel in die proses van korporatiewe beheer. Die SAIGR (1998) het 'n riglyn uitgereik in sy reeks oor korporatiewe beheer wat leiding aan direkteure i.v.m. die beoordeling van 'n interne ouditafdeling verskaf.

\subsection{Inligting in die jaarverslae aangaande interne oudit}

In $37 \%(47 \%)$ van die jaarverslae word 'n aanduiding gegee dat die maatskappy ' $n$ interne ouditafdeling het. By 46\% (40\%) van die jaarverslae word daar ook verdere inligting oor die verantwoordelikhede, effektiwiteit, ens. van die interne ouditafdeling gegee.

\section{$7 \quad$ Etiese kodes en die onderskrywing van die King- verslag}

\subsection{Inleiding}

Die "hart" van die King-verslag (1994:31-35) is die etiese kode (code of corporate practices and conduct). 'n Sodanige etiese kode vorm 'n belangrike deel van die korporatiewe beheerproses (vergelyk ook die Kingverslag 1994:25).

\subsection{Etiese kode van die maatskappy}

Van die maatskappye se jaarverslae het 73\% (59\%) aangetoon dat hulle wel oor 'n etiese kode beskik. In 96\% (95\%) van die jaarverslae word inligting oor die onderskrywing van die King-verslag verstrek. Altesaam 92\% (89\%) van die jaarverslae dui aan dat die verslag ten volle onderskryf word en $8 \%$ (11\%) onderskryf slegs sekere aspekte daarvan.

'n Aspek wat vanjaar vir die eerste keer ondersoek is, is of besonderhede van die etiese kode in die jaarverslag verskyn en of die implementeringswyse van die etiese kode in die jaarverslag vermeld word. In $40 \%$ van die gevalle wat ondersoek is, verskyn besonderhede inderdaad in die jaarverslag, terwyl die implementeringswyse van die kode in $47 \%$ van die verslae uitgespel word. 


\section{$8 \quad$ Risiko}

\subsection{Inleiding}

Veral weens die toenemende verantwoordelikhede wat maatskappye teenoor uiteenlopende groepe belanghebbendes moet aanvaar, is die beoordeling van finansiële en ander risiko-areas 'n belangrike aspek van korporatiewe beheer.

\subsection{Inligting aangaande risiko}

Die jaarverslae van $94 \%(71 \%)$ van die matskappye bevat inligting aangaande die benadering wat gevolg word ter identifisering van beduidende risiko-areas en inligting oor die bestuur van sulke risiko-aspekte. In die lig van die agtergrond wat in 1 gegee is aangaande risikobestuur en die "nuwe" King-verslag wat gedurende 2001 sal verskyn, kan verwag word dat hierdie inligting in die toekoms waarskynlik baie sal toeneem.

\section{$9 \quad$ Werknemerbetrokkenheid}

Die werknemers van 'n onderneming is 'n belangrike groep belanghebbendes. Sonder dié groep se aktiewe steun sal dit waarskynlik baie moeilik, indien nie onmoontlik nie, wees om 'n goeie kultuur van korporatiewe beheer in 'n maatskappy te vestig. Die King-verslag (1994:7) meld dat "we believe that workers should participate in the governance of corporations". In 74\% (39\%) van die jaarverslae word die wyse aangetoon waarop werknemers aan die proses van korporatiewe beheer van die maatskappy deelneem.

\section{$10 \quad$ Samevatting}

Dit word weer eens beklemtoon dat die resultate van die ondersoek vanjaar omsigtig beoordeel moet word aangesien die finansiële state van slegs 167 maatskappye vanjaar ondersoek is. Hierdie 167 maatskappye kan egter as die toonaangewers beskou word, aangesien hulle as die "top maatskappye" geklassifiseer word, gebaseer op hul bates. 'n Vergelyking met die resulte van die ondersoek van die vorige jaar moet dus in dié lig gesien word, maar kan ook 'n aanduiding gee van die reslultate onder "groter" maatskappye teenoor dié wat die hele spektrum van genoteerde maatskappye verteenwoordig.

Die volgende is die belangrikste bevindings wat uit hierdie opname spruit: 
- Nieteenstaande die aanbeveling in die King-verslag dat die ampte van voorsitter van die direksie en van uitvoerende hoofbestuurder geskei sal wees, is daar verlede jaar bevind dat dit in slegs $47 \%$ van die gevalle gegeld het. Vanjaar se ondersoek toon dat daar in $52 \%$ van die gevalle ' $n$ sodanige onderskeid is. Dit mag wees dat die $52 \%$ die tendens slegs onder "groter" maatskappye weerspieël. Dit bly kommerwekkend dat onder die toonaangewende maatskappye 'n beduidende persentasie van $48 \%$ nie aan hierdie riglyn voldoen nie.

- Verslae oor die interne beheerstelsel word deur 96\% (93\%) van die maatskappye verskaf, meestal in die verslag oor korporatiewe beheer. In $40 \%$ van die gevalle is die mening van die direkteure dat die stelsel "effektief" is, terwyl dit as "voldoende" in $11 \%$ van die gevalle beskou word.

- 'n Verklaring van die maatskappy om as 'n lopende saak voort te bestaan, word in $93 \%$ van die gevalle verstrek en is wesenlik konsekwent met die vorige jaar. In die meeste gevalle word hierdie verklaring in die verslag oor korporatiewe beheer verskaf, hoewel dit in ' $n$ minderheid van gevalle ook in die direkteursverslag uiteengesit word.

- In 54,5\% (43\%) van die gevalle word aangedui dat besluite oor wesenlike aangeleenthede by die direksie berus. Daar word steeds in 'n minderheid van gevalle (42,5\% teenoor $39,3 \%$ verlede jaar) aangedui dat die direksie volle en effektiewe beheer oor die maatskappy uitoefen. Alhoewel daar in beide gevalle 'n styging voorgekom het in vergelyking met die vorige jaar se bevindings, bly dit tog kommerwekkend dat relatief min maatskappye in hul finansiële jaarstate aandui dat hulle aan hierdie twee kernaspekte van korporatiewe beheer voldoen.

- Verreweg die meerderheid van maatskappye (80\% teenoor $66 \%$ verlede jaar) het vergoedingskomitees aangestel. Die meeste van die lede van die vergoedingskomitee is nie-uitvoerende direkteure $(69 \%$ teenoor $67 \%$ verlede jaar), terwyl in enkele gevalle ook eksterne persone in die vergoedingkomitees dien. Die grootste enkele groep onder die lede van vergoedingskomitees is geoktrooieerde rekenmeesters (19\% teenoor 30 verlede jaar).

- Dit kon waarskynlik voorsien word dat die "groter" maatskappye meer inligting, veral ook aangaande hul direkteure, in hul finansiële jaarstate bekend sou maak. Dit is egter vreemd dat in die huidige projek in $46,6 \%(36,8 \%)$ van die state die kwalifikasies van direkteure nie aangetoon word nie. Daar is geen voor die handliggende rede vir hierdie bykans $10 \%$ daling nie en dit mag dalk interessant wees om te probeer bepaal wat die rede vir hierdie tendens by "groter" maatskappye is. 
- In die meerderheid van gevalle (63\% teenoor $50 \%$ verlede jaar) word 'n onderskeid getref tussen die vergoeding van uitvoerende en nieuitvoerende direkteure en in $46 \%$ van die gevalle word die wyse waarop direkteursvergoeding bepaal word in die finansiële state openbaar.

- In $89 \%(80 \%)$ van die gevalle is ouditkomitees aangestel wat gemiddeld uit 3 (3) lede bestaan. Die minderheid van die lede van die ouditkomitee is uitvoerende direkteure (25\% teenoor $27 \%$ verlede jaar). Die grootste enkele groep onder die lede van ouditkomitees is geoktrooieerde rekenmeesters (28\% teenoor $45 \%$ verlede jaar).

- Die werksaamhede van die ouditkomitee word in verreweg die meeste gevalle ( $84 \%$ teenoor $70 \%$ verlede jaar) in die jaarverslag uitgespel.

- In 'n minderheid van gevalle (37\% teenoor $47 \%$ verlede jaar) word in die jaarverslae aangedui of die maatskappy oor 'n interne ouditafdeling beskik.

- $\quad$ Die meerderheid van maatskappye (73\% teenoor 59\% verlede jaar) het aangedui dat hulle oor 'n etiese kode beskik. In sommige gevalle $(40 \%)$ word besonderhede van die etiese kode en die implementeringswyse (47\%) daarvan in die jaarverslag gegee.

- Verreweg die meeste maatskappye (94\% teenoor $71 \%$ verlede jaar) verskaf inligting oor die identifisering van beduidende risiko-areas en inligting oor die bestuur van sodanige risiko-aspekte.

- In 74\% (39\%) van die gevalle word die wyse aangetoon waarop werknemers aan die proses van korporatiewe beheer deelneem. Die beduidende verskil tussen die syfers van verlede jaar en dié van vanjaar kan die gevolg wees daarvan dat slegs groter maatskappye vanjaar ingesluit is, maar dit kan ook dui op 'n groter mate van werkersdeelname.

In hierdie artikel is 'n ontleding aangebied van inligting aangaande korporatiewe beheer van toonaangewende genoteerde maatskappye in SuidAfrika. Dit is duidelik dat verskeie maatskappye dit hul erns maak om inligting aangaande hul nakoming van korporatiewe beheerriglyne in die jaarverslae te kommunikeer. Verskeie maatskappye in Suid-Afrika maak dit steeds nie hul erns nie, ten spyte van duidelike riglyne en vereistes wat oor korporatiewe beheer bestaan.

Daar word beplan om die ontleding, wat die grondslag van hierdie navorsing gevorm het, elke jaar te herhaal sodat vergelykbare inligting bekom kan word oor die vordering van genoteerde maatskappye in SuidAfrika met betrekking tot die implementering van korporatiewe beheerbeginsels en ten einde norme in dié verband te bepaal. Daar word vertrou dat genoteerde maatskappye kennis sal neem van hierdie pogings en voortdurend daarna sal streef om voldoende inligting aangaande 
korporatiewe beheer in hul jaarverslae te kommunikeer sodat die doelwitte van hierdie projek bereik kan word.

Daar kan verwag word dat die "nuwe King-verslag", wat gedurende 2001 uitgereik sal word, verskeie nuwe of "strenger" riglyne sal neerlê ooreenkomstig internasionale ontwikkelinge en eiesoortige Suid-Afrikaanse behoeftes. In die lig hiervan sal hierdie deurlopende navorsingsprojek waardevolle inligting oor die vordering met die implementering van bestaande en toekomstige gewysigde korporatiewe beheerriglyne daarstel.

\section{Bibliografie}

Department of Finance. 2000. Government Notice - Municipal Finance Management Bill, Department of Finance.

Die Suid-Afrikaanse Instituut van Geoktrooieerde Rekenmeesters. 1997. Guidance for directors: Reporting on internal control, Corporate Governance Guide, Die Suid-Afrikaanse Instituut van Geoktrooieerde Rekenmeesters, Kengray.

Die Suid-Afrikaanse Instituut van Geoktrooieerde Rekenmeesters. 1998. Guidance for directors: the role of internal audit, Corporate Governance Guide, Die Suid-Afrikaanse Instituut van Geoktrooieerde Rekenmeesters, Kengray.

KPMG. 1999. Shaping the audit committee agenda, KPMG LLP.

Lubbe, D.S. \& Henning, J. 2000(a). King-komitee is dalk nodig vir die openbare sektor, Sake-Burger, 18 Augustus 2000, p.58.

Lubbe, D.S. \& Henning, J. 2000(b). Is King-komitee nodig vir die openbare sektor? Sake-Beeld, 22 Augustus 2000, p.12.

Lubbe, D.S. \& Henning, J. 2000(c). King-komitee vir dié sektor? SakeVolksblad, 14 Augustus 2000, p.3.

Lubbe, D.S. \& Van der Merwe, J. G. 1996. Reporting by audit committees in annual financial statements, Accounting \& Finance Update, August 1996, pp.16-18.

Marrs, D. 2000. King Report under review, Business Day, 1 August 2000, p.1. 
Marx, B. 1992. 'n Kritiese ondersoek na die ontwikkeling en funksionering van die ouditkomitee in Suid-Afrika, Ongepubliseerde M.Compt. verhandeling. Universiteit van die Oranje-Vrystaat, Bloemfontein.

Marx, B. \& Lubbe, D.S. 1993. Enkele empiriese bevindinge aangaande die funksionering van ouditkomitees by groot maatskappye in Suid-Afrika, Meditari 1 Vol. 1, pp.43-60.

PricewaterhouseCoopers. 1999. Audit committees: good practices for meeting market expectations, PricewaterhouseCoopers.

Republic of South Africa. 1999. Public Finance Management Act (Act No. I of 1999), Republic of South Africa.

Republiek van Suid-Afrika. 1999. Maatskappywysigingswetsontwerp (Wet 17 van 1999), Republiek van Suid-Afrika.

SEC, NYSE \& NASD. 1999. Improving the effectiveness of corporate audit committees (The Blue Ribbon Report), SEC, NYSE \& NASD.

The Institute of Directors in Southern Africa. 1994. The King Report on Corporate Governance, The Institude of Directors in Southern Africa, Parkland, Johannesburg.

Van der Merwe, J.G. 1996. Die invloed van die ouditkomitee op die eksterne ouditproses, Ongepubliseerde M.Com.-verhandeling, Universiteit van Pretoria, Pretoria

Von Keyserlingk, C. 2000. IOD sal King-beginsels verfyn, Sake-Rapport, 13 Augustus 2000, p.3.

Vorster, Q. \& Lubbe, D. S. 1999. Enkele bevindings aangaande die nakoming van sekere korporatiewe beheerriglyne in die jaarverslae van genoteerde Suid-Afrikaanse maatskappye, Meditari Vol. 7, pp.277-290. 